\title{
As cidades brasileiras encontram uma síntese
}

Jaime Tadeu Oliva ${ }^{1}$

RISÉRIO, Antonio. A cidade no Brasil.

São Paulo: Editora 34, 2012. 367 p.

Antes de qualquer comentário interno sobre o livro de Antonio Risério (A cidade no Brasil), antecipamos que o leitor está diante de um livro de grande qualidade. Trata-se de um trabalho de um escritor de fato, visto as propriedades estilísticas e comunicativas do texto, o que, convenhamos, não é pouca coisa. A qualidade textual, somada aos outros predicados gerais do livro, oferece uma boa oportunidade para exercitar uma tolerância crítica necessária, raramente praticada. Entenda-se: pode-se discordar de muitas de suas interpretações e teses, mas elas são sempre inteligentes. $\mathrm{O}$ fato do pensamento do autor não coincidir com o do leitor não pode ser razão para desqualificar a obra. Isso seria o exercício de uma "razão simplória".

Antonio Risério não é propriamente um acadêmico e sim um representante raro do intelectual público, ensaísta. Mas, diferentemente de muitos intelectuais célebres, cujo brilhantismo que os sustentavam nem sempre era alimentado por fontes sólidas, Risério exibe um extraordinário controle de uma bibliografia de fôlego, ao mesmo tempo especializada e interdisciplinar (e intercultural), e um uso de fontes importantes para construir sua narrativa. Nem mesmo as teses acadêmicas que ainda não tiveram uma edição comercial deixaram de ser consultadas. Portanto, revela-se no livro um intelectual livre das várias injunções e vícios que infestam os textos acadêmicos, mas que não nega a produção intelectual produzida no âmbito acadêmico. De certo modo, seria justo afirmar que o autor consegue realizar (e bem) esse trânsito entre a ordem acadêmica específica e a ordem cultural geral.

1 Professor Doutor e Pesquisador do Instituto de Estudos Brasileiros da Universidade de São Paulo (USP, São Paulo, SP, Brasil). E-mail: jtoliva@gmail.com 
Interessante, ainda como preâmbulo, notar que o contexto dos estudos e das publicações sobre o mundo urbano brasileiro não se beneficia das obras de síntese que em algum momento precisam ser escritas, para que se organize e se estabeleça parâmetros nas análises e nas interpretações. Raríssimas são as tentativas de síntese mesmo junto aos especialistas das áreas que num momento ou outro se deparam com o objeto urbano. Por isso, é de se louvar a síntese iniciada por Risério. E ela realmente é produtiva na função de organizadora das discussões e análises relevantes na área. O Brasil é um país urbano, mesmo onde olhos mais convencionais não enxergam esse conteúdo e modo de vida. Sua urbanização é vasta, diversa e de grandes dimensões. Grande parte das questões sociais e nacionais está mediada (ou condicionada) pelas características das cidades e dos espaços urbanos derivados. A centralidade da questão urbana parece indubitável, porém, à sua importância não correspondem estudos e publicações condizentes. A pobreza dos estudos urbanos é chocante. Essa é mais uma razão para recepcionar com entusiasmo o esforço de Risério.

O autor anuncia desde as primeiras páginas a sua pretensão de produzir uma história ensaística da cidade no Brasil (com fortes traços do antropólogo que ele é). E já no início, para justificar os precedentes remotos da cultura urbana do Brasil, que ele vai buscar no "tripé formador" do país (o indígena - diverso certamente -, o africano - complexo certamente - e o português), Risério se obriga a uma contenda não muito clara com um presumido conceito ocidental-europeu de cidade, que marcado culturalmente, etnocêntrico, não apreende nem contempla o que teria sido uma cultura urbana do indígena amazônico e mesmo dos grupos africanos traficados como escravos para o Brasil, pois tal conceito exige que a cidade tenha um espaço construído durável. Isso não é totalmente justo tendo em vista certos avanços teóricos no campo dos estudos urbanos, que são cultivados por autores geógrafos europeus (ver Le Tournant geographique de Jacques Lévy e L'Homme spacial de Michel Lussault, por exemplo), cujo conceito de cidade tem abrangência extracultural e universalidade admitindo, a princípio, com muita boa vontade a possibilidade de um mundo urbano indígena, mesmo que efêmero no tempo e volátil no espaço tal como Risério assinala sobre o urbanismo iorubano: "que considerava a cidade mais como um modo de vida de uma comunidade vivente do que um espaço materialmente construído" (p. 42).

Ocorre que no livro a questão conceitual da cidade é enfrentada de soslaio, na medida da necessidade da argumentação do autor, porém os argumentos se sustentam apenas parcialmente, na medida de algumas circunstâncias. Quer dizer: não prevalece, com clareza, uma definição 
de cidade que, além de orientar a questão da procedência ou não da existência de um mundo urbano amazônico pré-colonização, oriente o conjunto da narrativa e outras celeumas que o autor vai incorporando ao longo da narrativa. É justo notar que são apresentados bons "inícios de conversa" sobre o que seria o mundo urbano, sobre o que seria a cidade. No entanto, a impressão é que ele não se esmerou nessa direção, porque não seria preciso. Afinal, quem não sabe o que é cidade, ou o que é o mundo urbano: trata-se de um truísmo.

Sobre o que seria uma cidade, pode-se atualizar a célebre passagem de Santo Agostinho sobre o tempo (algo como: "ah, o tempo, claro que sei o que é, mas não me pergunte, porque aí já não sei mais”). Então, não me pergunte o que é cidade ou sobre seus derivados: o urbano, o modo de vida urbano.

Talvez a questão conceitual relativamente pendente sobre a cidade termine por interferir também na aposta do potencial explicativo da história da formação das cidades brasileiras que o autor parece fazer. Não é por outro motivo que ele descreve a urbanização da África précolonização, notando que essa inicia-se alguns séculos antes da Era Cristã. O leitor pode, nesse caso, supor que haveria alguma relação de continuidade com o posterior mundo urbano brasileiro. Eis como o autor trata a questão da formação cultural com a presumida repercussão sobre as cidades brasileiras: "Vamos nos deter, brevemente, em dois povos que foram fundamentais para a formação, a invenção e a consolidação da sociedade e da cultura brasileiras: os bantos e os iorubanos" (p. 39).

A erudita e notável reconstituição histórica da experiência urbana dos povos formadores da cultura brasileira, examinada separadamente tem grande valor, mas ao se avaliar o peso que esta história teria na constituição do mundo urbano brasileiro, pode-se duvidar que as permanências tenham sido relevantes. Também pudera: os espaços citadinos têm na sua substância a função relacional, afinal os humanos não se aglomeram em espaços que visam a distância zero, para evitar o contato. E o contato levado à sua condição exponencial faz da cidade uma "máquina relacional" que tende a destruir o passado e construir novas realidades: São Paulo da virada do século XIX para o XX é uma cidade estrangeira em relação à atual. Por outro lado, seria injusto dizer que o autor nega esse último raciocínio, o que faz com que a queixa no "excesso explicativo da história" tenha que ser relativizada. Um exemplo é a maneira de Risério relatar e intervir na ainda hipervalorizada e já superada discussão sobre a influência do caráter português do colonizador (o semeador que não planejava) nas cidades brasileiras e sobre a racionalidade espanhola (o ladrilhador que planejava) nas cidades 
hispânicas da América Latina: "A diferença entre a cidade lusa e a cidade hispânica, no Novo Mundo, não está no plano. Mas, no que aconteceu com o plano, em sua implantação objetiva no continente americano" (p. 64). E ainda nessa direção o autor vai se posicionar claramente ao lado desse papel transformador da cidade ao enfrentar uma velha contenda que opõe o campo e a cidade: "por que a chama criativa queima na cidade e não no campo?” (p. 174) Assim, ele enuncia os termos dessa discussão oferecendo repertório interessante e consistente para o entendimento do que está se conflitando nas posições pró-campo e pró-cidade.

Outro aspecto que gostaríamos de ressaltar e que ainda se relaciona com certa oscilação conceitual sobre a cidade se refere a uma ausência de crítica direta (no grosso essa crítica pode ser depreendida em alguns momentos, mas ela é instável) à associação da ideia de ordem urbana aos planos e de desordem à ausência de planos explícitos. Planos urbanos geométricos supõem apenas uma modalidade de ordem e se somarmos a essa ordem geométrica outros elementos como a setorização e hierarquização dos planos de extração corbusiana (e Brasília não escapa substancialmente desse modelo) aí mesmo é que veremos o quanto essa ordem é marcada culturalmente, é específica, isso para não dizer "uma visão de classe social". É bom lembrar a célebre crítica de Jane Jacobs quando assinala que o contrário do planejamento não é a desordem, e investe contra as cidades radiosas de Corbusier, dizendo que essas, sim, criam um tipo de desordem que afeta o citadino que reivindica uma cidade com urbanidade. Em suma, a palavra ordem, pelo que discrimina, termina sempre sendo uma desorganizadora do discurso, pelo alto teor de concentração ideológica que ela carrega e daí a superestimação dos planos e do planejamento quando o tema é a avaliação crítica das cidades. Ora, planos e planejamento podem atuar contra a urbanidade das cidades, podem desintegrá-las e criar espaços cujo horizonte seja a segregação social, o afastamento e não o contato. E Risério sabe bem disso, e não deixa de enfrentar questões do gênero nos capítulos finais do seu trabalho, onde queríamos dar um destaque especial ao tema da segregação, drama contemporâneo e cada vez mais acirrado que infelicita nossas cidades, que se beneficia bastante do talento e sensibilidade do autor, e padece um pouquinho com a suposição de que há um conceitual sobre cidade que seja estável e de conhecimento de todos. De todo modo, o alvissareiro, pela qualidade do que já está concretizado nesse livro, é que o autor pensa em permanecer no tema para nos oferecer outros textos, que agora poderão tratar mais do presente das cidades brasileiras que, repetindo, clamam por estudos e interpretações (mesmo que diversos e contrapostos), mas desse quilate do livro de Risério. 